\title{
Identification of Ground Water Potential Zones Using GIS and Remote Sensing Techniques in the Case of Odiyo Watershed, Ethiopia
}

Habtamu Deribe ( $\sim$ habtader@gmail.com )

Bonga University https://orcid.org/0000-0002-1527-4405

Dereje Biru Debalke

Bonga University

\section{Research}

Keywords: Analytical hierarchical process, Weighted Overlay Analysis, Potential groundwater zone, GIS and RS

Posted Date: May 19th, 2021

DOI: https://doi.org/10.21203/rs.3.rs-239478/v1

License: (c) (i) This work is licensed under a Creative Commons Attribution 4.0 International License. Read Full License 


\section{Abstract}

Background: The current study conducted to analysis the bottom water potential zones in Odiyo watershed. The study relies on the secondary data, which is collected from concern department and through internet. Totally nine parameters are consider for the study like drainage density, elevation, geology, geomorphology, land use and land cover, lineaments, rainfall pattern, slope gradient and soil texture. The chosen parameters are prepared and classified in GIS environment, then weightage for every parameter and its classes are assigned using Analytical Hierarchical Process, and eventually, weighted overlay analysis in

ArcGIS accustomed discover the result.

Results: The result relived that, about 183.87ha (0.613\%) areas are having very high, 4846.23ha (16.18\%) area are having high, 19229.4 ha $(64.19 \%)$ having moderate, 5645.7 ha $(18.855)$ having low and 48.6 ha $(0.16 \%)$ area are having very low potential of well water.

Conclusions: The knowledge on strength of ground water supported ground water zones help in management and development of the groundwater within the study area.

\section{Background}

Ground water resources are a crucial resource for its use in domestic, agriculture and industries purposes. There has been an incredible increase within the demand for groundwater thanks to increase in population, advanced irrigation practices, and industrial usages (Jha et al., 2007). Hence, unscientific exploitation and improper use of water policy are possible factors. Therefore, the assessment of groundwater resources is critical for sustainable management. Most groundwater potential investigation techniques (i.e., geophysical methods, ground based survey, and exploratory drilling) are uneconomical and time consuming and large data sets (Nampak, pradhan, and Manap, 2014; Singh and prakash). However, an integrated GIS and remote sensing study can provide the suitable platform for the convergent analysis of enormous volumes of information and quite higher cognitive process techniques for groundwater exploration.

Recently, several studies are applied using weighted overlay analysis for assessing groundwater potential zones (Tolche, 2020; Andualem \& Demeke, 2019; Das, Pal, Malik, \& Rabin Chakrabortty, 2019; Hussein, Govindu, \& Nigusse, 2016; Ibrahim-Bathis \& Ahmed, 2016; Kumar, Herath, Avtar, \& Takeuchi, 2016; Magesh, Chandrasekar, \& Soundranayagam, 2012; Rahmati, Samani, Mahdavi, Pourghasemi, \& Zeinivand, 2014). Among many determent factors of the occurrence and movement of groundwater, topography, geomorphology, lithology, geological structures, lineaments, porosity, slope, drainage patterns, rainfall, LULC, water quality, depth to water, net groundwater recharge, and climate may be listed as examples (Tolche, 2020; Andualem \& Demeke, 2019; Elewa \& Qaddah, 2011; Jaiswal, Mukherjee, Krishnamurthy, \& Saxena, 2003; Jha, Chowdhury, Chowdary, \& Peiffer, 2007; Murthy \& Mamo, 2009). Hence, the factors are a different per researcher, and consequently, the results vary (Magesh et al., 2012).

Groundwater potential zone mapping in Odiyo watershed will have a big effect within the sub basin furthermore because the country. Since the watershed is that the major part to contribute to Omo River; mapping the underground water will enhance sustainable management of groundwater resources within the country. As a result, the current study interested to delineate the groundwater potential zones by using remote sensing and GIS technologies within the study area. Nine determinant factors, namely, lithology, slope, LULC, rainfall, lineaments, geomorphology, elevation, soil texture and drainage density, were accounted for within the study.

\section{Study Area}

The study area Odiyo watershed is found within the center portion of Omo basin, Ethiopia. Geographically, the study site is situated between latitude $7^{\circ} 7 \otimes 0^{\prime \prime}$ to $7^{\circ} 25 \otimes 0^{\prime \prime}$ n and longitude $36^{\circ} 23 \otimes 0^{\prime \prime}$ to $36^{\circ} 40 \varangle 30^{\prime \prime}$ e with an aerial extent of $315.52 \mathrm{~km}^{2}$ (Fig. 1) .the elevation of the area ranges from 3219 to $1190 \mathrm{~m}$ above average sea level. In step with the national meteorology report, the mean annual rainfall of the area is varies from 1536.7 to $1644.9 \mathrm{~mm}$ and the mean annual temperature ranges from $12.4^{\circ} \mathrm{C}$ to 21.5 ${ }^{\circ} \mathrm{C}$. 


\section{Methodology}

In order to identify the ground water potential zone within the study area various kinds of data and software are used (Table 1).All criteria employed during this study were first geo-referenced and converted into a raster format to make ready for reclassification and standardization. Following, all the factors were reclassified using ArcGIS spatial analysis tool supported their groundwater availability rank. Their levels of groundwater availability were decided supported data collected from the varied scientific literature. Thus, all the factors were classified into five classes (very high, high, moderate, low and very low) with values ranging from 1 to 5 , where 1 represents very low and 5 represents very high. For each criterion, Weights were derived in IDRISI software using AHP methods. All the standardized criteria were combined using weighted overlay analysis to produced ground water Potential Zones Map of the study area. The sources of the quality data used for the delineation of groundwater Potential Zones Map and availability levels were supported published scientific literature as indicated in Table 2. The overall framework of the research study analysis is presented in Fig. 2 .

Table 1

Summary of data types and their sources

\begin{tabular}{|lllll|}
\hline No & Type of data & Source of data & $\begin{array}{l}\text { Scale/Resolution } \\
\text { /Format }\end{array}$ & Functions \\
\hline 1 & $\begin{array}{l}\text { Landsat 8 Operational Land } \\
\text { Imager (OLI) satellite image }\end{array}$ & USGS & $30 \star 30 \mathrm{~m}$ & $\begin{array}{l}\text { Used to generate lineament density map } \\
\text { of the study area }\end{array}$ \\
\hline 2 & Spot 6 & EGIA & $1.5 * 1.5 \mathrm{~m}$ & $\begin{array}{l}\text { Used to generate Land use Land cover } \\
\text { map of the study area }\end{array}$ \\
\hline 3 & A digital elevation model (DEM) & SRTM & $30 \star 30 \mathrm{~m}$ & $\begin{array}{l}\text { Used to derive slope, elevation, } \\
\text { Geomorphology and drainage density } \\
\text { map }\end{array}$ \\
\hline 5 & $\begin{array}{l}\text { The rainfall data of } 36 \\
\text { years(1980-2016) }\end{array}$ & NMA & Excel Format & $\begin{array}{l}\text { Used to generate Rainfall map of the } \\
\text { study area }\end{array}$ \\
\hline 6 & $\begin{array}{l}\text { Soological data } \\
\text { Sata }\end{array}$ & $\begin{array}{l}\text { Ethiopian } \\
\text { geological survey }\end{array}$ & $\begin{array}{l}\text { at a scale of 1: } \\
250,000\end{array}$ & $\begin{array}{l}\text { Used to generate Geological map of the } \\
\text { study area }\end{array}$ \\
\hline
\end{tabular}


Table 2

Criteria considered for Groundwater potential zone selection.

\begin{tabular}{|c|c|c|c|c|c|}
\hline Criteria & Unit & Class & Value & $\begin{array}{l}\text { Ground water } \\
\text { availability }\end{array}$ & Source \\
\hline & & Clay & 1 & Very low & \\
\hline \multirow[t]{4}{*}{ Soil texture } & Class & Clay loam & 2 & Low & $\begin{array}{l}\text { (Tripathi et al,2017; FAO, } \\
\text { 1998) }\end{array}$ \\
\hline & & Sandy clay loam & 3 & Moderate & \\
\hline & & Sandy loam & 4 & High & \\
\hline & & Sandy and wetland & 5 & Very high & \\
\hline \multirow[t]{5}{*}{ LULC } & Class & Others & 1 & Very low & \\
\hline & & Built up & 2 & Low & \\
\hline & & Waterbody & 3 & Moderate & $\begin{array}{l}\text { (Mahalingam and Vinay, } \\
\text { 2015). }\end{array}$ \\
\hline & & Agricultural area & 4 & High & \\
\hline & & Forest & 5 & Very high & \\
\hline \multirow[t]{5}{*}{ Geology } & Class & - & 1 & Very low & \\
\hline & & Metamorphic rocks & 2 & Low & (Mwega et al., 2013) \\
\hline & & Igneous rocks & 3 & Moderate & \\
\hline & & - & 4 & High & \\
\hline & & Sedimentary rocks & 5 & Very high & \\
\hline \multirow[t]{5}{*}{ Geomorphology } & Class & Salt crust & 1 & Very low & \\
\hline & & Salt domes and Layer & 2 & Low & \\
\hline & & Hills, plateaus and Badlands & 3 & Moderate & $\begin{array}{l}\text { (Ghodratabadi and Feizi, } \\
\text { 2015) }\end{array}$ \\
\hline & & $\begin{array}{l}\text { Plain surfaces between } 500 \text { and } \\
1000 \mathrm{~m}\end{array}$ & 4 & High & \\
\hline & & $\begin{array}{l}\text { Mountain with an altitude of } 500 \\
\text { meters. }\end{array}$ & 5 & Very high & \\
\hline
\end{tabular}


Table 3

Software and materials employed in the study

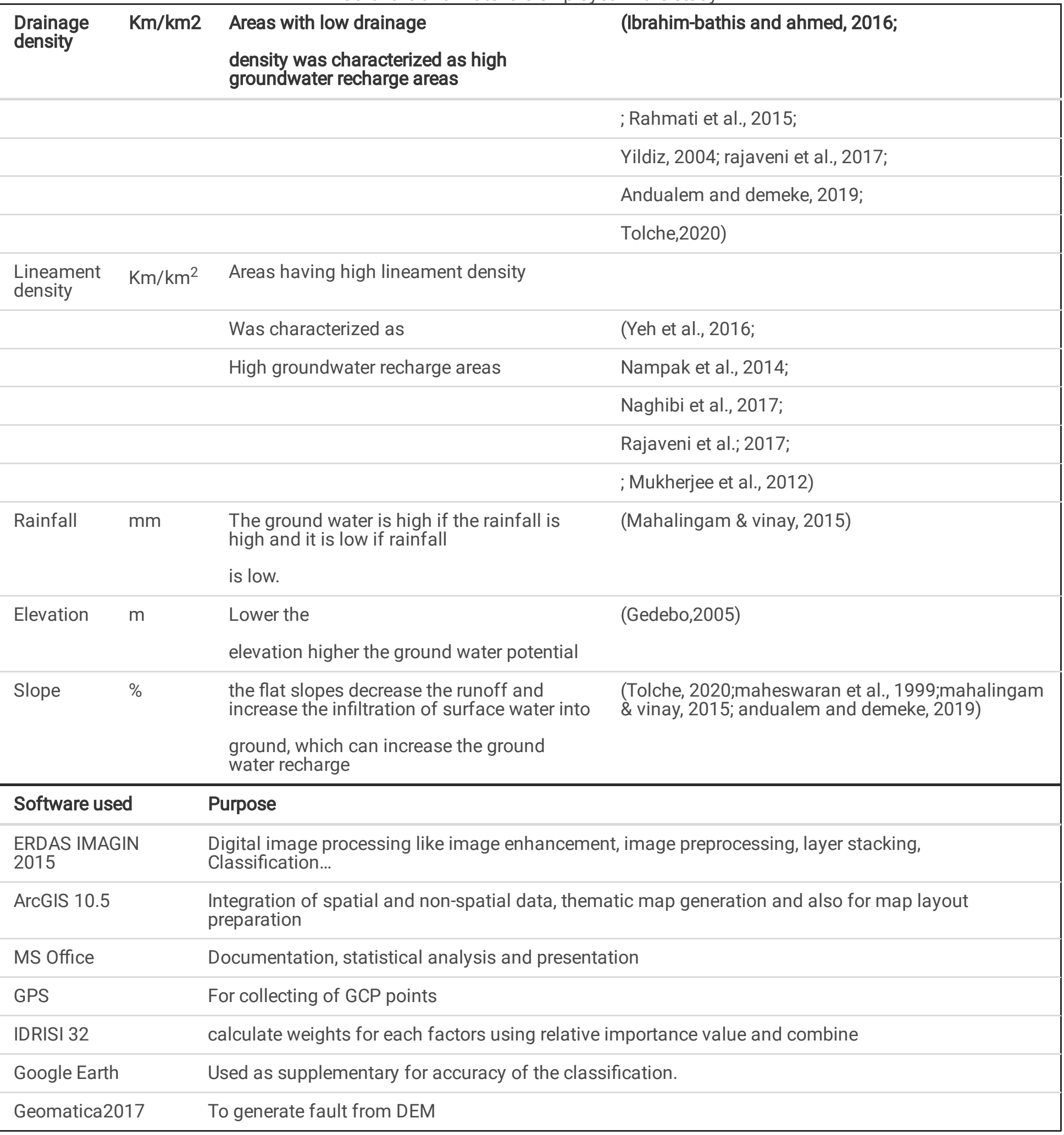

\section{Results And Discussion}

\subsubsection{Drainage density}

The drainage density has an inverse relation with the permeability of aquifers and plays a significant role within the runoff distribution and level of infiltration (Ibrahim-Bathis and Ahmed, 2016; Rahmati et al., 2015; Yildiz, 2004; Rajaveni et al., 2017; 
Tolche, 2020). The drainage density of the study area was prepared from the digital elevation model ( $30 \mathrm{~m} \times 30 \mathrm{~m}$ resolution) in ArcGIS 10.5 platform. The drainage density has been classified into five classes (Table 4 and Fig. 3 )

Table 4

Drainage density class with respective Ground water availability.

\begin{tabular}{|lllll|}
\hline Drainage class & Ground water availability & Value & Area (ha) & Area (\%) \\
\hline $3.20-5.11$ & very low & 1 & 1540.867 & 4.883016 \\
\hline $3.20-2.28$ & Low & 2 & 4915.437 & 15.57705 \\
\hline $2.28-1.44$ & Moderate & 3 & 8636.156 & 27.36803 \\
\hline $1.44-0.54$ & High & 4 & 4722.647 & 14.9661 \\
\hline $0-0.54$ & very high & 5 & 11740.53 & 37.2058 \\
\hline
\end{tabular}

\subsubsection{Lineament density}

Lineament density is directly proportional to groundwater potential (Andualema and Demeke, 2019). Areas with high lineament density are good for groundwater potential zones (Yeh et al., 2016; Nampak et al., 2014; Naghibi et al., 2017; Rajaveni et al.; 2017; Mukherjee et al., 2012; Tolche,2020). The Lineament density of the study area was prepared Landsat 8 (OLI) satellite image captured in January 2020 in Geomatic 17 platform. Then Lineament density has been classified into five classes (Table 5 and Fig. 4)

Table 5

Lineament density class with respective Ground water availability.

\begin{tabular}{|lllll|}
\hline Lineament class & Ground water availability & Value & Area (ha) & Area (\%) \\
\hline $0-022$ & very low & 1 & 11689.41 & 37.04381 \\
\hline $0.22-0.64$ & low & 2 & 8463.812 & 26.82187 \\
\hline $0.64-1.10$ & moderate & 3 & 6321.204 & 20.03194 \\
\hline $1.10-1.69$ & high & 4 & 3855.088 & 12.2168 \\
\hline $1.69-2.90$ & very high & 5 & 1226.121 & 3.885585 \\
\hline
\end{tabular}

\subsubsection{Rainfall}

The possibility of ground water is high if the rainfall is high and it is low if rainfall is low (Mahalingam and Vinay, 2015). This study has been considering the annual mean rainfall from the year 1980 to 2016. the worth of annual mean values are plated on the respective rain gage stations and also the interpolation method Krigging has been wont to learn the distribution of rainfall within the study area. Once the spatial distribution of rainfall has been found the study area has been classified into five zones supported the equal interval (Table 6 and Fig. 5)

Table 5

Rainfall class with respective Ground water availability.

\begin{tabular}{|lllll|}
\hline Rainfall class & Ground water availability & Value & Area (ha) & Area (\%) \\
\hline $1537-1554$ & very low & 1 & 4248.45 & 13.45838 \\
\hline $1554-1566$ & low & 2 & 8105.67 & 25.67741 \\
\hline $1566-1580$ & moderate & 3 & 14348.34 & 45.45315 \\
\hline $1580-1606$ & high & 4 & 3456.27 & 10.94889 \\
\hline $1606-1645$ & very high & 5 & 1408.59 & 4.462178 \\
\hline
\end{tabular}

Page 6/23 


\subsubsection{Elevation}

Water tends to store at lower topography instead of the upper topography. Higher the elevation lesser the ground water potential and the other way around as Gedebo,(2005) citied in Mahalingam and Vinay,(2015). For this study elevation data having 30meter spatial resolution has been created supported the ASTER DEM. The study area's elevation ranges between 1189 meters to 3163 meters from the mean water level, this value are classified equally into five classes (Table 7 and Fig. 6)

Table 7

Elevation class with respective Ground water availability.

\begin{tabular}{|lllll|}
\hline Elevation class & Ground water availability & Value & Area (ha) & Area (\%) \\
\hline $2758-3163$ & very low & 1 & 5299.02 & 16.78641 \\
\hline $2442-2758$ & low & 2 & 6188.4 & 19.60382 \\
\hline $2127-2442$ & moderate & 3 & 9012.87 & 28.55127 \\
\hline $1728-2127$ & high & 4 & 6340.68 & 20.08622 \\
\hline $1189-1728$ & very high & 5 & 4726.35 & 14.97229 \\
\hline
\end{tabular}

\subsubsection{Slope}

Slope determines the speed of infiltration and runoff of surface water, the flat surface areas can hold and drain the water within the bottom, which might increase the ground water recharge whereas the steep slopes increase the runoff and reduce the infiltration of surface water into ground (Mahalingam and Vinay, 2015). The slope of the study area has been calculated in percent supported the DEM model which was supported the ASTER data. The slope has been classified into five classes (Table 8 and Fig. 7)

Table 8

Slope class with respective Ground water availability.

\begin{tabular}{|lllll|}
\hline Slope class & Ground water availability & Value & Area (ha) & Area (\%) \\
\hline $17.01-26.28$ & very low & 1 & 1874.34 & 5.937596 \\
\hline $12.42-17.01$ & low & 2 & 4428.27 & 14.02802 \\
\hline $8.45-12.42$ & moderate & 3 & 6795.09 & 21.52571 \\
\hline $4.78-8.45$ & high & 4 & 9931.41 & 31.46105 \\
\hline $0.29-4.78$ & very high & 5 & 8538.21 & 27.04762 \\
\hline
\end{tabular}

\subsubsection{Soil Texture}

The rate of infiltration largely depends on the grain size and related hydraulic characteristics of the soils (Fashae et al., 2014). Soil texture of the study area is studied from the soil data collected from agricultural department. The study reveals three soil texture class in odiyo watershed namely clay and clay loam. Rank of soil has been assigned on the premise of their infiltration rate (Tripathi et al, 2017). Clay and clay loam soil have low infiltration rate (Table 9 and Fig. 8)

Table 9

Soil texture class with respective Ground water availability.

\begin{tabular}{|lllll|}
\hline Texture class & Ground water availability & Value & Area (ha) & Area (\%) \\
\hline Clay & very low & 1 & 1990.17 & 6.304526 \\
\hline Clay Loam & low & 2 & 29577.15 & 93.69547 \\
\hline
\end{tabular}




\subsubsection{Land use and Land cover (LU/LC)}

The surface covered by vegetation like forests and agriculture traps and holds the water in root of plants whereas the built-up and rocky land use affects the recharge of groundwater by increasing runoff during the rain, so it is necessary to check what quite features are covered the study area's land surface. The spot 6 satellite image has been used for the study to seek out the land use and land cover of study area. The supervised classification method has been used with maximum likelihood. The results of the study found the study area covered by six different classes like agricultural land, forest, built-up, water body, bare and others (Table 10 and Fig. 9).

Table 10

LULC class with respective Ground water availability.

\begin{tabular}{|lllll|}
\hline LULC class & Ground water availability & Value & Area (ha) & Area (\%) \\
\hline Others & very low & 1 & 3197.958 & 10.14243 \\
\hline Built up & low & 2 & 25.5708 & 0.081099 \\
\hline Water body & moderate & 3 & 13458.87 & 42.68527 \\
\hline Agriculture & high & 4 & 1336.882 & 4.239967 \\
\hline Forest & very high & 5 & 13511.2 & 42.85123 \\
\hline
\end{tabular}

\subsubsection{Geomorphology}

Geomorphology reflects various landform and topographical features. Surface water is one in every of the important geomorphological agents within the development and shaping of landscapes and landforms; thus hydro-geomorphological studies are of importance in planning and execution of groundwater exploration (Fashae et al. 2014). Geomorphic features within the study area are dominated by hill, and mountain. It is classified in terms of groundwater potentiality (Table 11 and Fig. 10) supported pervious literature (Ghodratabadi and Feizi, 2015)

Table 11

Geomorphology class with respective Ground water availability.

\begin{tabular}{|llccc|}
\hline $\begin{array}{l}\text { Geomorphology } \\
\text { class }\end{array}$ & Ground water availability & Value & Area (ha) & Area (\%) \\
\hline Hills & moderate & 3 & 1937.745 & 6.142923 \\
\hline Mountain & very high & 5 & 29606.61 & 93.85708 \\
\hline
\end{tabular}

\subsubsection{Geology}

Groundwater occurrence and its movement depend on the geological setting. Major geological classification of the watershed is ingenious rocks. Geological features of the study area are later classified in terms of groundwater potentiality (Table 12 and Fig. 11) based on pervious literature (Mwega, 2013).

Table 12

Geomorphology class with respective Ground water availability.

\begin{tabular}{|lllll|}
\hline Geology class & Ground water availability & Value & Area (ha) & Area (\%) \\
\hline Igneous rock & Moderate & 5 & 31544.35 & 100 \\
\hline
\end{tabular}

\subsection{Weight assignment to parameters}

The results of the study indicate that the consistency ratio is 0.03 . this is less than 0.1 which is acceptable to continue and apply the AHP method analysis (Saaty,1980).Based on the IDIRISI_AHP weight derivation module, the following eigenvector weights for 
all criteria considered for groundwater potential zone selection were generated (Table 14).In summary, the results of the AHP weight derivation reveals that parenthetically, soil texture plays an important role with the best score weight of $31.21 \%$ followed by geology,geomorphology,LULC, rainfall, lineament density, drainage density, elevation and slope with score weight of $22.23 \%$, $15.55 \%, 10.75 \%, 7.39 \%, 5.07 \%, 3.5 \%, 2.47 \%$ and $1.83 \%$, respectively. A region having high lineament density was given high weight and the other way around (Ibrahim-Bathis and Ahmed, 2016; Naghibi et al., 2017; Nampak et al., 2014; Yeh et al., 2016). a part having high drainage density was assigned very low weight (Tolche,2020;Andualem \& Demeke, 2019; Ibrahim-Bathis \& Ahmed, 2016; Rahmati et al., 2014).whereas steep slope area assigned to low weight (Andualem \& Demeke, 2019; Hussein et al., 2016; Ibrahim-Bathis \& Ahmed, 2016).

Table 13

Pair wise comparison in 9 point continuous scale.

\begin{tabular}{|c|c|c|c|c|c|c|c|c|c|}
\hline & Texture & Geology & Geomorphology & LULC & Rainfall & Lineament & Drainage & Elevation & Slope \\
\hline Texture & 1 & & & & & & & & \\
\hline Geology & $1 / 2$ & 1 & & & & & & & \\
\hline Geomorphology & $1 / 3$ & $1 / 2$ & 1 & & & & & & \\
\hline LULC & $1 / 4$ & $1 / 3$ & $1 / 2$ & 1 & & & & & \\
\hline Rainfall & $1 / 5$ & $1 / 4$ & $1 / 3$ & $1 / 2$ & 1 & & & & \\
\hline Lineament & $1 / 6$ & $1 / 5$ & $1 / 4$ & $1 / 3$ & $1 / 2$ & 1 & & & \\
\hline Drainage & $1 / 7$ & $1 / 6$ & $1 / 5$ & $1 / 4$ & $1 / 3$ & $1 / 2$ & 1 & & \\
\hline Elevation & $1 / 8$ & $1 / 7$ & $1 / 6$ & $1 / 5$ & $1 / 4$ & $1 / 3$ & $1 / 2$ & 1 & \\
\hline Slope & $1 / 9$ & $1 / 8$ & $1 / 7$ & $1 / 6$ & $1 / 5$ & $1 / 4$ & $1 / 3$ & $1 / 2$ & 1 \\
\hline
\end{tabular}

Table 14

Weights derived by calculating the principal eigenvector of pair wise comparison matrix.

\begin{tabular}{|lll|}
\hline Factor & Eigenvector Weight & Percentage (\%) \\
\hline Soil texture & 0.3121 & 31.21 \\
\hline Geology & 0.2223 & 22.23 \\
Geomorphology & 0.1555 & 15.55 \\
\hline LULC & 0.1075 & 10.75 \\
\hline Rainfall & 0.0739 & 7.39 \\
Lineament & 0.0507 & 5.07 \\
\hline Drainage & 0.035 & 3.5 \\
\hline Elevation & 0.0247 & 2.47 \\
\hline Slope & 0.0183 & 1.83 \\
\hline & 1 & 100 \\
\hline Consistency ratio & 0.03, consistency is acceptable. \\
\hline
\end{tabular}

\subsection{Delineation of groundwater potential zones}

After the weightage of each parameter has been determined. Finally, 'Spatial overlay method in Arc GIS environment is employed to conduct overly analysis to get the intended result. The results of overlay analysis has been classified into five classes as very low, low, moderate, high and very high (Fig. 12). From the results of classification it is been found that, about 183.87 ha $(0.613 \%)$ 
areas are having very high, 4846.23ha (16.18\%) area are having high, 19229.4 ha (64.19\%) having moderate, 5645.7ha (18.855) having low and $48.6 \mathrm{ha}(0.16 \%)$ area are having very low potential of ground water (Table 15$)$. Very high and high groundwater potential zones are concentrated within the area where, high lineament density was illustrated united of the basic factors for groundwater potential zonation (Ibrahim-Bathis \& Ahmed, 2016). The low to very low potential zones are mainly distributed within the areas having high drainage density. Hence, the groundwater potential in these areas may be not sufficient for irrigation and other livelihood requirements. Therefore, groundwater development activities preferred to be performed in high groundwater prospective zones.

Table 15

Groundwater potential area and percentage of the study area.

\begin{tabular}{|llll|}
\hline Ground water availability & Value & Area (ha) & Area (\%) \\
\hline very low & 1 & 48.6 & 0.16225 \\
\hline low & 2 & 5645.7 & 18.84803 \\
\hline moderate & 3 & 19229.4 & 64.19686 \\
\hline high & 4 & 4846.23 & 16.17902 \\
\hline very high & 5 & 183.87 & 0.613845 \\
\hline
\end{tabular}

\section{Conclusion}

The study on groundwater potential through integration and weightage overlay analysis in GIS environment using physical parameters that influence the groundwater is being successfully applied during this study. The methodology begins with the preparation of thematic layers from different data sources and next deriving the weights using overlay analysis to search out groundwater potential. The weightage is assigned to different layers and overlaid to realize the intended result groundwater potential zones of odiyo watershed. The thematic layers are first assigned the weightage supported the precise importance of the category in individual parameters. The layers are then overlaid and therefore the result's then classified into five class supported groundwater availability to namely; very high, high, and moderate, low and very low. The knowledge obtained on the groundwater prospectus of the study area will be accustomed identify and extract the potable water for the domestic and irrigational purposes.

\section{Declarations}

\section{Ethics approval and consent to participate}

Informed consent was obtained from all student participants involved in the study. All participants freely agreed to participate in the study without reservation.

\section{Funding}

The authors are not received any fund.

\section{Consent for publication}

Consent to publish individual data in any form was obtained from the participants interviewed.

\section{Availability of data and materials}

Not applicable' for that section

\section{Competing interest}

The authors declare no competing interests. 
Habtamu D and Dereje B conceived and designed the work validated the method section. Both authors participated in the analysis, validation and writing of the paper. Both authors read and approved the final manuscript.

\section{Acknowledgment}

The authors are highly indebted to all secondary data provider organizations. The authors are also grateful to those individuals who assist in different stages of this work. We acknowledge the comments from anonymous reviewers.

\section{References}

1. Andualem TG, Demeke GG (2019) Groundwater potential assessment using GIS and remote sensing: A case study of Guna tana landscape, upper Blue Nile Basin, Ethiopia. Journal of Hydrology: Regional Studies 24:100610

2. Das B, Pal SC, Malik S, Rabin Chakrabortty R (2019) Modeling groundwater potential zones of Puruliya district, West Bengal, India using remote sensing and GIS techniques. Geology, Ecology, and Landscapes, 3(3), 223-237

3. Elewa HH, Qaddah AA (2011) Groundwater potentiality mapping in the Sinai Peninsula, Egypt, using remote sensing and GISwatershed-based modeling. Hydrogeol J 19(3):613-628

4. FAO (1998) World reference base for soil resources. World soil resources reports 84:21-22

5. Fashae OA et al (2014) Delineation of Groundwater Potential Zones in the Crystalline Basement Terrain of SWNigeria: An Integrated GIS and Remote Sensing Approach. Applied Water Science 4:19-38

6. Ghodratabadi S, Feizi F (2015) Identification of groundwater potential zones in Moalleman, Iran by remote sensing and index overlay technique in GIS. Iranian Journal of Earth Sciences 7(2):142-152

7. Hussein A, Govindu V, Nigusse AGM (2016) Evaluation of groundwater potential using geospatial techniques. Applied Water Science 7(5):2447-2461

8. Ibrahim-Bathis K, Ahmed SA (2016) Geospatial technology for delineating groundwater potential zones in Doddahalla watershed of Chitradurga district. India. The Egyptian Journal of Remote Sensing Space Sciences 19(2):223-234

9. Jaiswal RK, Mukherjee S, Krishnamurthy J, Saxena R (2003) Role of remote sensing and GIS techniques for generation of groundwater prospect zones towards rural development - An approach. Int J Remote Sens 24(5):993-1008

10. Jha MK, Chowdhury A, Chowdary VM, Peiffer S (2007) Groundwater management and development by integrated remote sensing and geographic informationsystems: Prospects and constraints. Water Resour Manage 21(2):427-467

11. Kumar P, Herath S, Avtar R, Takeuchi K (2016) Mapping of groundwater potential zones in Killinochi area, Sri Lanka, using GIS and remote sensing techniques. Sustainable Water Resources Management 2(4):419-430

12. Magesh NS, Chandrasekar N, Soundranayagam JP (2012) Delineation of groundwater potential zones in Theni district, Tamil Nadu, using remote sensing, GIS and MIF techniques. Geoscience Frontiers, 3(2), 189-196. Malczewski, J. (1999). GIS and multicriteria decision analysis. New York: Wiley

13. Mahalingam B, Vinay M (2015) Identification of ground water potential zones using GIS and Remote Sensing Techniques: A case study of Mysore taluk-Karnataka. International Journal of Geomatics Geosciences 5(3):393-403

14. Maheswaran M, Ali S, Siegel HJ, Hensgen D, Freund RF (1999) Dynamic mapping of a class of independent tasks onto heterogeneous computing systems. J Parallel Distrib Comput 59(2):107-131

15. Mukherjee P, Singh CK, Mukherjee S (2012) Delineation of groundwater potential zones in arid region of India-a remote sensing and GIS approach. Water Resour Manag 26(9):2643-2672

16. Murthy KSR, Mamo AG (2009) Multi-criteria decision evaluation in groundwater zones identification in Moyale-Teltele subbasin, South Ethiopia. Int J Remote Sens 30(11):2729-2740

17. Mwega BW, Mati BM, Mulwa JK, Kituu GM (2015) Application of electrical resistivity method to investigate groundwater potential in Lake Chala watershed. International Academic Research for Multidisciplinary, 3(7)

18. Nagaraju A, Sreedhar Y, Thejaswi A, Dash P (2016) Integrated Approach Using Remote Sensing and GIS for Assessment of Groundwater Quality and Hydrogeomorphology in Certain Parts of Tummalapalle Area, Cuddapah District, Andhra Pradesh, South India. Advances in Remote Sensing 5(02):83 
19. Naghibi SA, Moghaddam DD, Kalantar B, Pradhan B, Kisi O (2017) A comparative assessment of GIS-based data mining models and a novel ensemble model in groundwater well potential mapping. J Hydrol 548:471-483

20. Nampak H, Pradhan B, Manap MA (2014) Application of GIS based data driven evidential belief function model to predict groundwater potential zonation. J Hydrol 513:283-300

21. Nampak H, Pradhan B, Manap MA (2014) Application of GIS based data driven evidential belief function model to predict groundwater potential zonation. J Hydrol 513:283-300

22. Rahmati O, Samani AN, Mahdavi M, Pourghasemi HR, Zeinivand H (2014) Groundwater potential mapping at Kurdistan region of Iran using analytic hierarchy process and GIS. Arab J Geosci 8(9):7059-7071

23. Rahmati O, Samani AN, Mahdavi M, Pourghasemi HR, Zeinivand H (2015) Groundwater potential mapping at Kurdistan region of Iran using analytic hierarchy process and GIS. Arab J Geosci 8(9):7059-7071

24. Rajaveni SP, Brindha K, Elango L (2017) Geological and geomorphological controls on groundwater occurrence in a hard rock region. Appl Water Sci 7(3):1377-1389

25. Singh AK, Prakash SR (2002) An integrated approach of remote sensing, geophysics and GIS to evaluation of groundwater potentiality of Ojhala subwatershed, Mirzapur district, UP, India. In Proceedings of the First Asian Conference on GIS, GPS, Aerial Photography and Remote Sensing, Bangkok, Thailand

26. Tolche AD (2020) Groundwater potential mapping using geospatial techniques: a case study of Dhungeta-Ramis sub-basin, Ethiopia. Geology, Ecology, and Landscapes, 1-16

27. Tripathi R, Shyju K, Jasim HR EVALUATION OF GROUND WATER POTENTIAL OF NALLATANGAAL ODAI USING REMOTE SENSING AND GIS TECHNIQUES

28. Yeh HF, Cheng YS, Lin HI, Lee CH (2016) Mapping groundwater recharge potential zone using a GIS approach in Hualian River, Taiwan. Sustainable Environment Research 26(1):33-43

29. Yildiz O (2004) An investigation of the effect of drainage density on hydrologic response. Turk J Eng Environ Sci 28(2):85-94

\section{Figures}




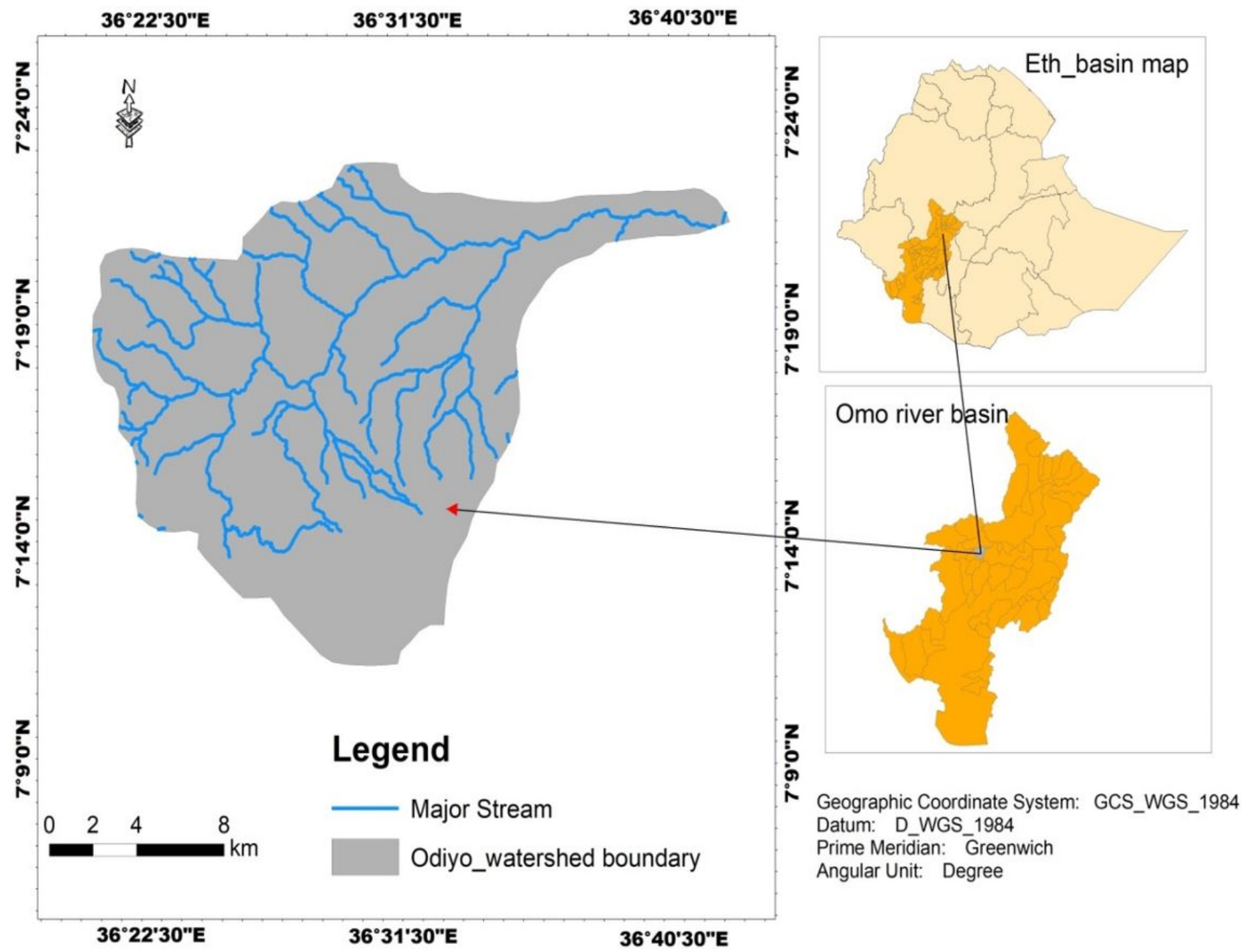

Figure 1

Locational map of odiyo watershed Note: The designations employed and the presentation of the material on this map do not imply the expression of any opinion whatsoever on the part of Research Square concerning the legal status of any country, territory, city or area or of its authorities, or concerning the delimitation of its frontiers or boundaries. This map has been provided by the authors. 

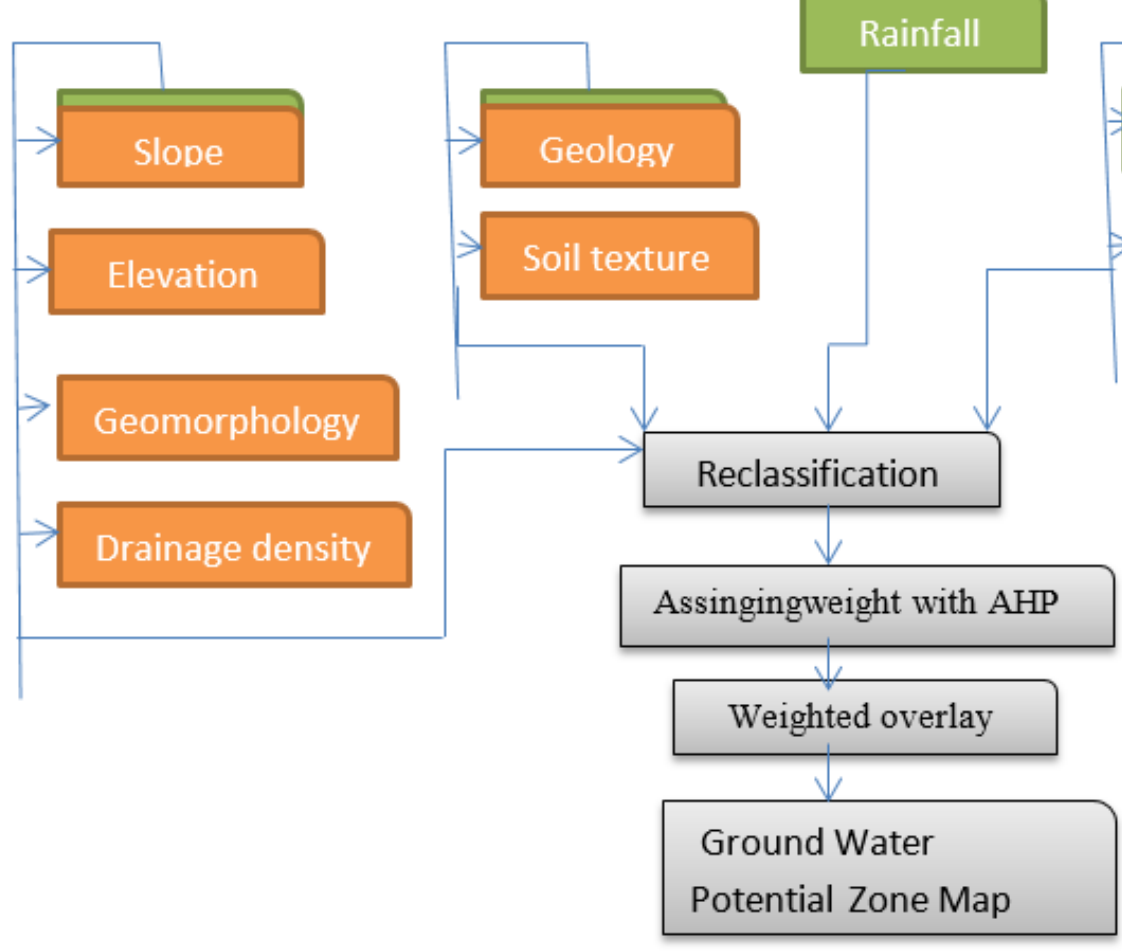

Lineament density

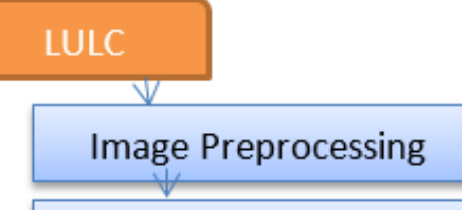

Supervised Classification

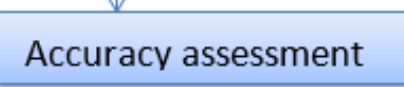

\section{Figure 2}

Methodological flowchart

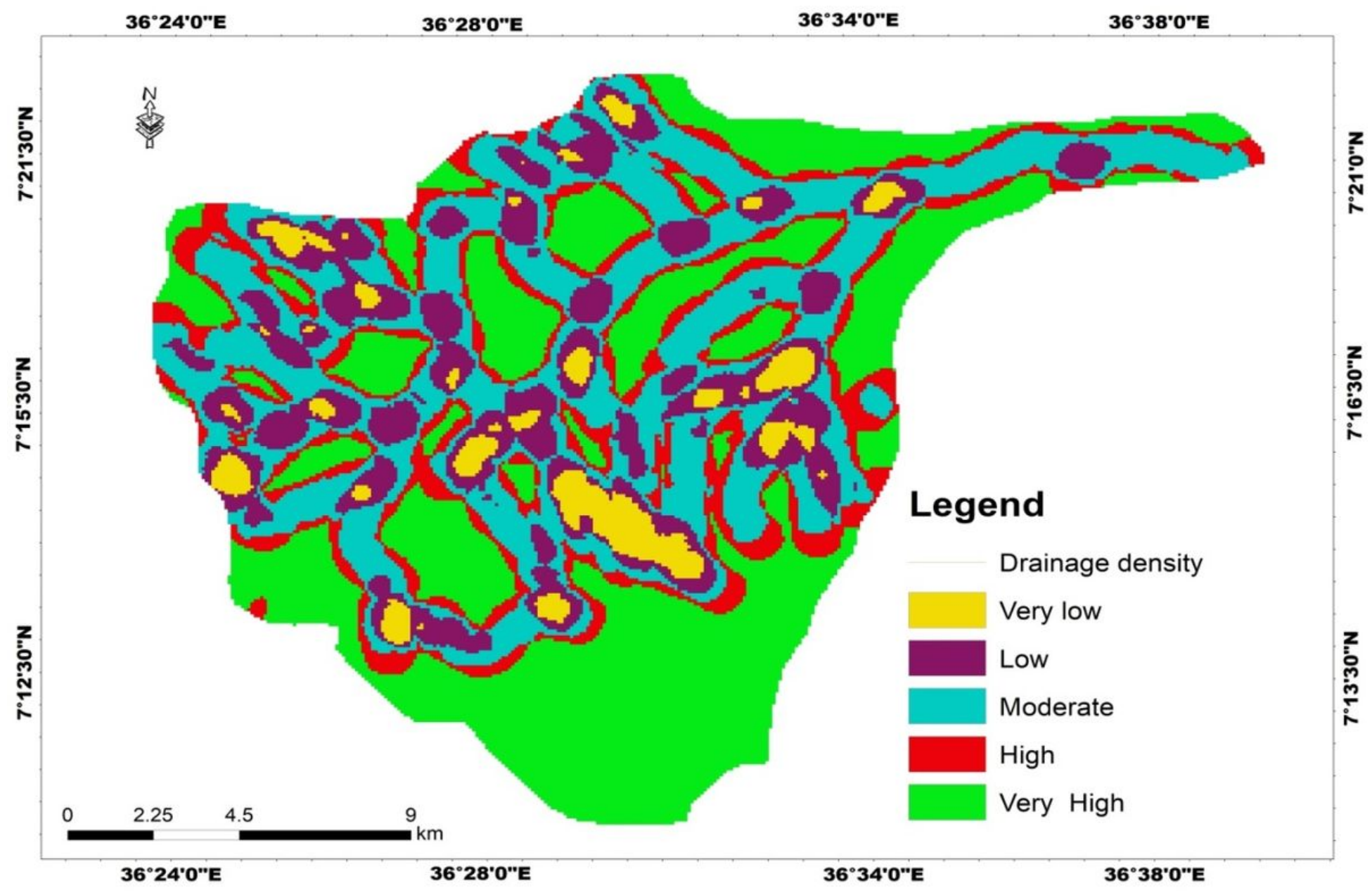


Figure 3

Reclassified Drainage density map. Note: The designations employed and the presentation of the material on this map do not imply the expression of any opinion whatsoever on the part of Research Square concerning the legal status of any country, territory, city or area or of its authorities, or concerning the delimitation of its frontiers or boundaries. This map has been provided by the authors.

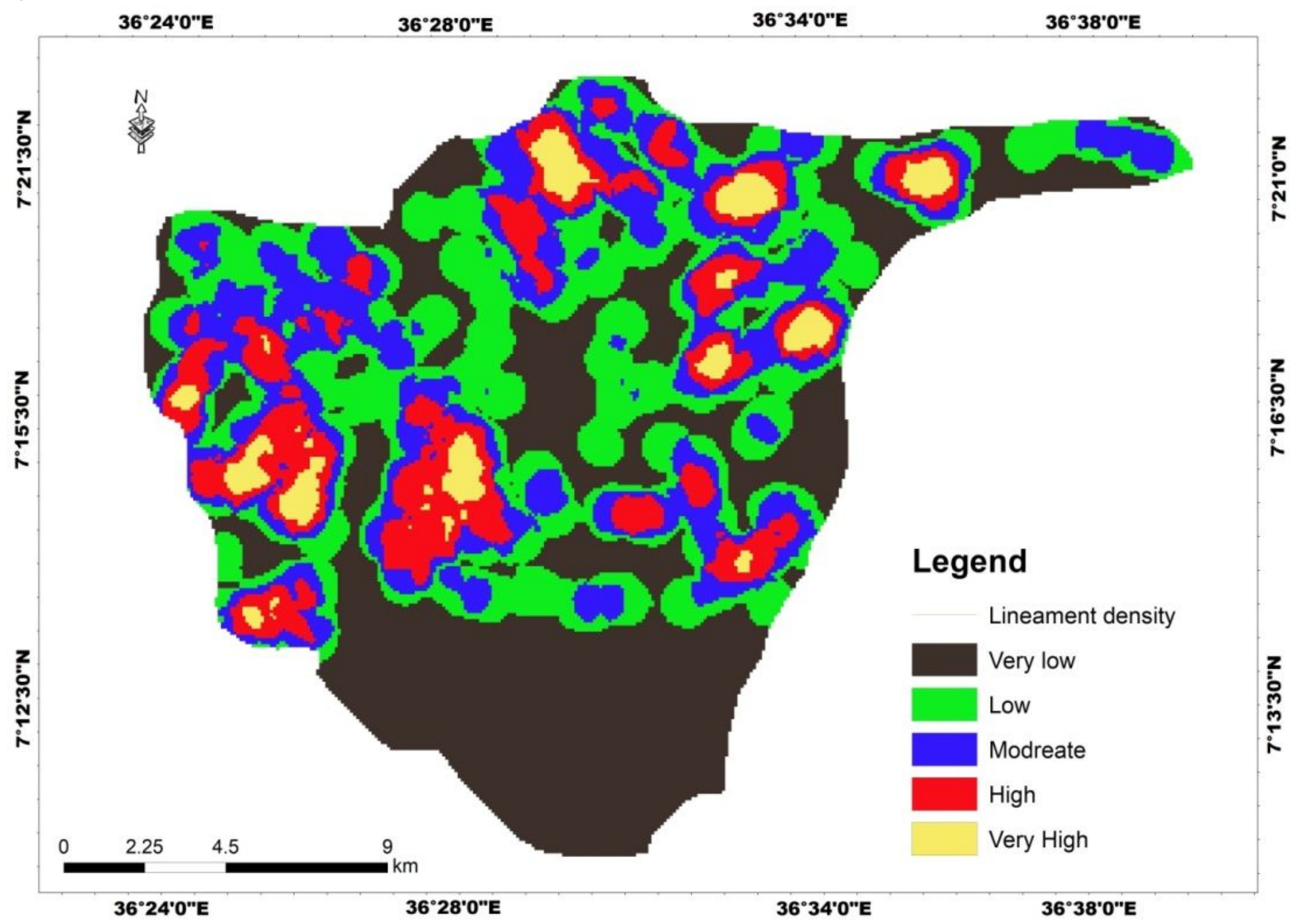

Figure 4

Reclassified Lineament density map. Note: The designations employed and the presentation of the material on this map do not imply the expression of any opinion whatsoever on the part of Research Square concerning the legal status of any country, territory, city or area or of its authorities, or concerning the delimitation of its frontiers or boundaries. This map has been provided by the authors. 


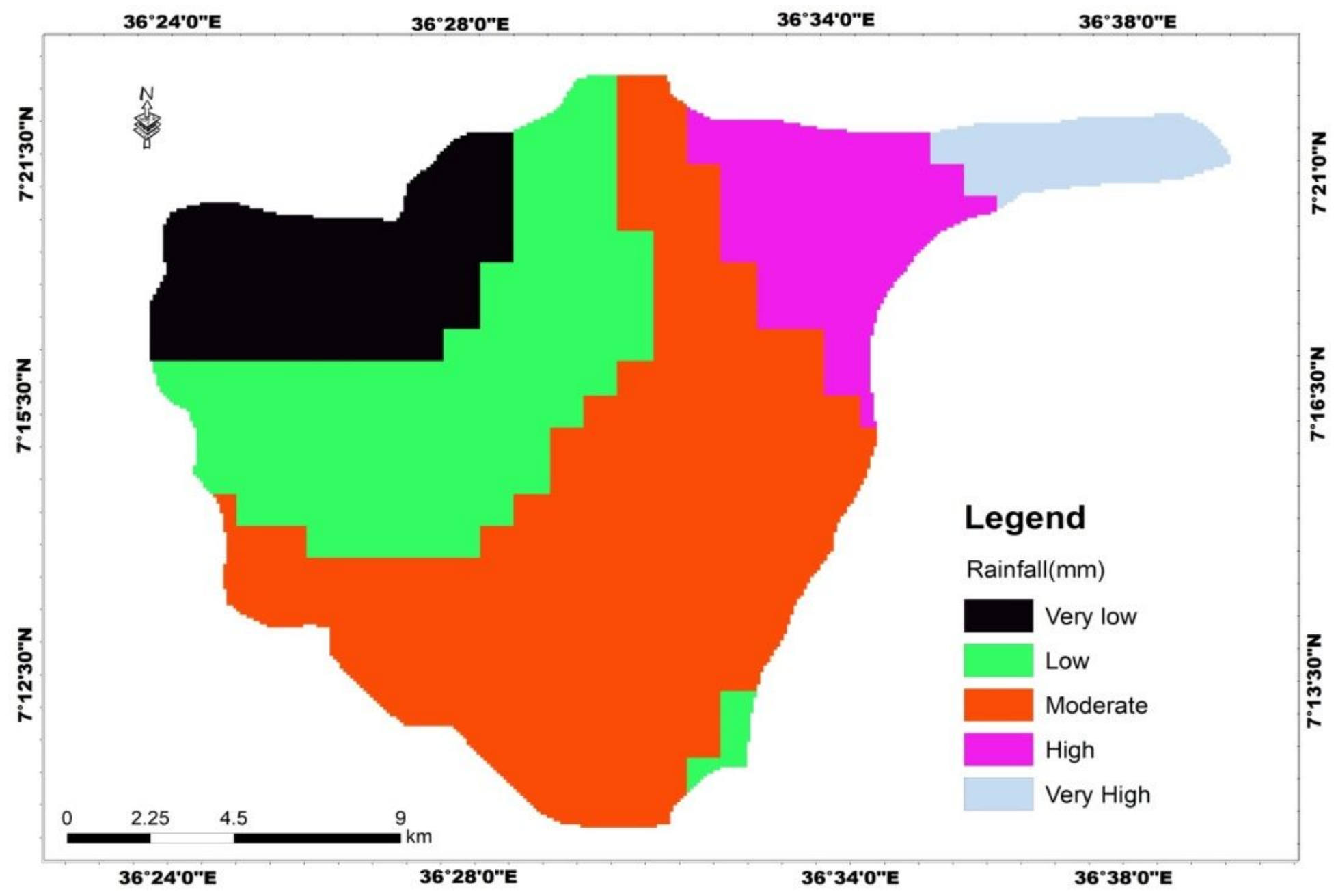

Figure 5

Reclassified Rainfall map. Note: The designations employed and the presentation of the material on this map do not imply the expression of any opinion whatsoever on the part of Research Square concerning the legal status of any country, territory, city or area or of its authorities, or concerning the delimitation of its frontiers or boundaries. This map has been provided by the authors. 


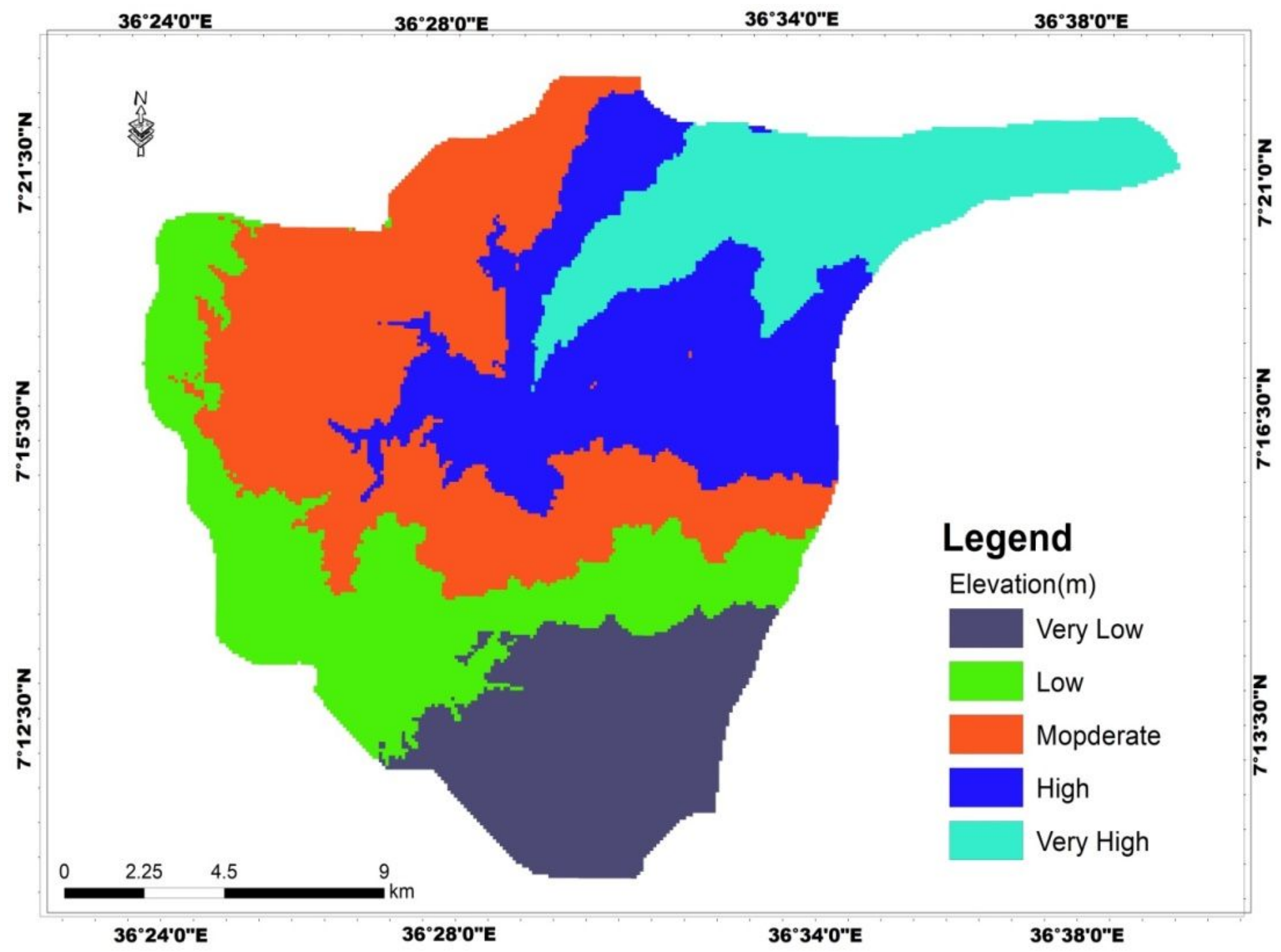

Figure 6

Reclassified Elevation map. Note: The designations employed and the presentation of the material on this map do not imply the expression of any opinion whatsoever on the part of Research Square concerning the legal status of any country, territory, city or area or of its authorities, or concerning the delimitation of its frontiers or boundaries. This map has been provided by the authors. 


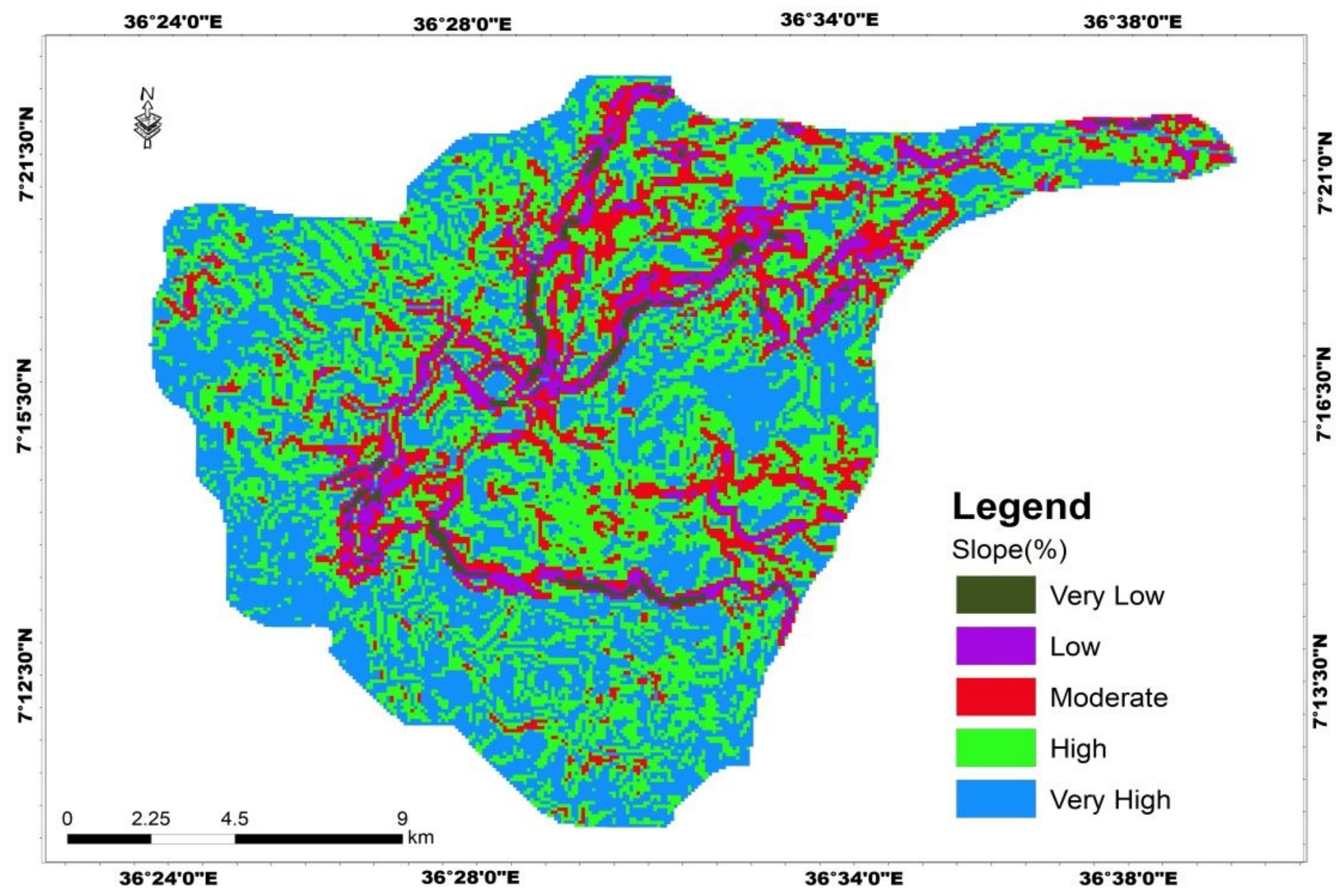

Figure 7

Reclassified Slope map. Note: The designations employed and the presentation of the material on this map do not imply the expression of any opinion whatsoever on the part of Research Square concerning the legal status of any country, territory, city or area or of its authorities, or concerning the delimitation of its frontiers or boundaries. This map has been provided by the authors. 


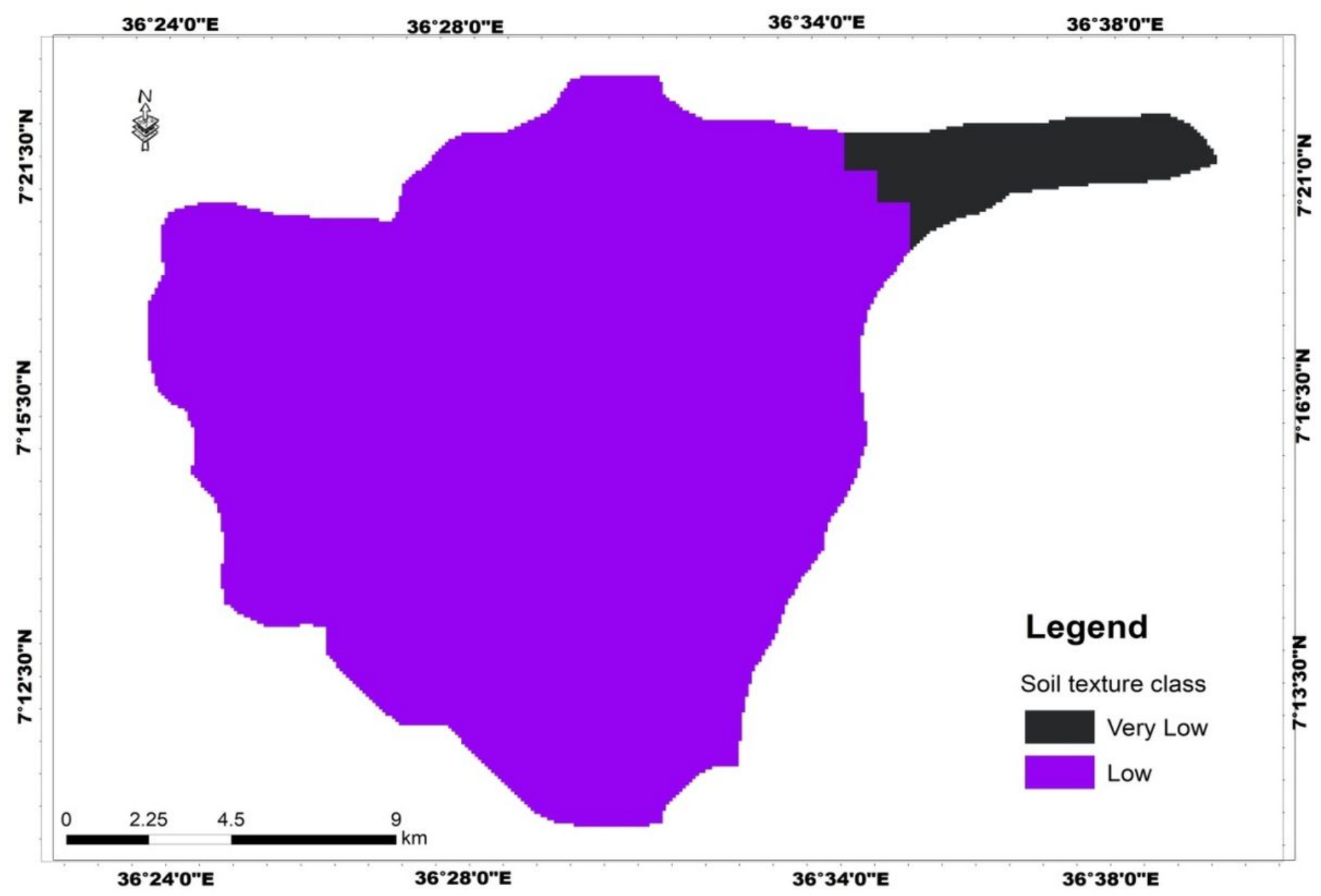

Figure 8

Reclassified Soil texture map. Note: The designations employed and the presentation of the material on this map do not imply the expression of any opinion whatsoever on the part of Research Square concerning the legal status of any country, territory, city or area or of its authorities, or concerning the delimitation of its frontiers or boundaries. This map has been provided by the authors. 


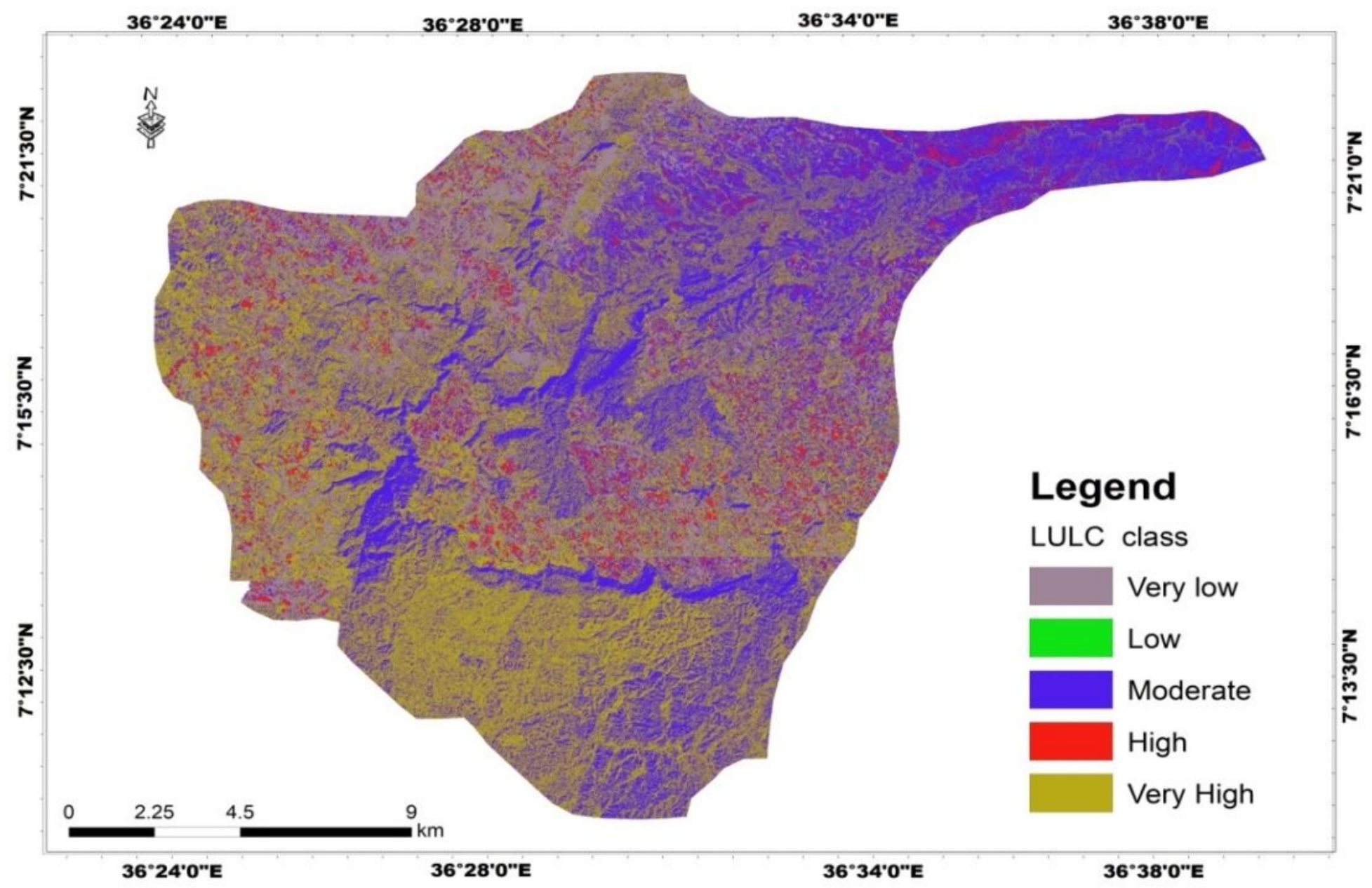

Figure 9

Reclassified LULC map. Note: The designations employed and the presentation of the material on this map do not imply the expression of any opinion whatsoever on the part of Research Square concerning the legal status of any country, territory, city or area or of its authorities, or concerning the delimitation of its frontiers or boundaries. This map has been provided by the authors. 


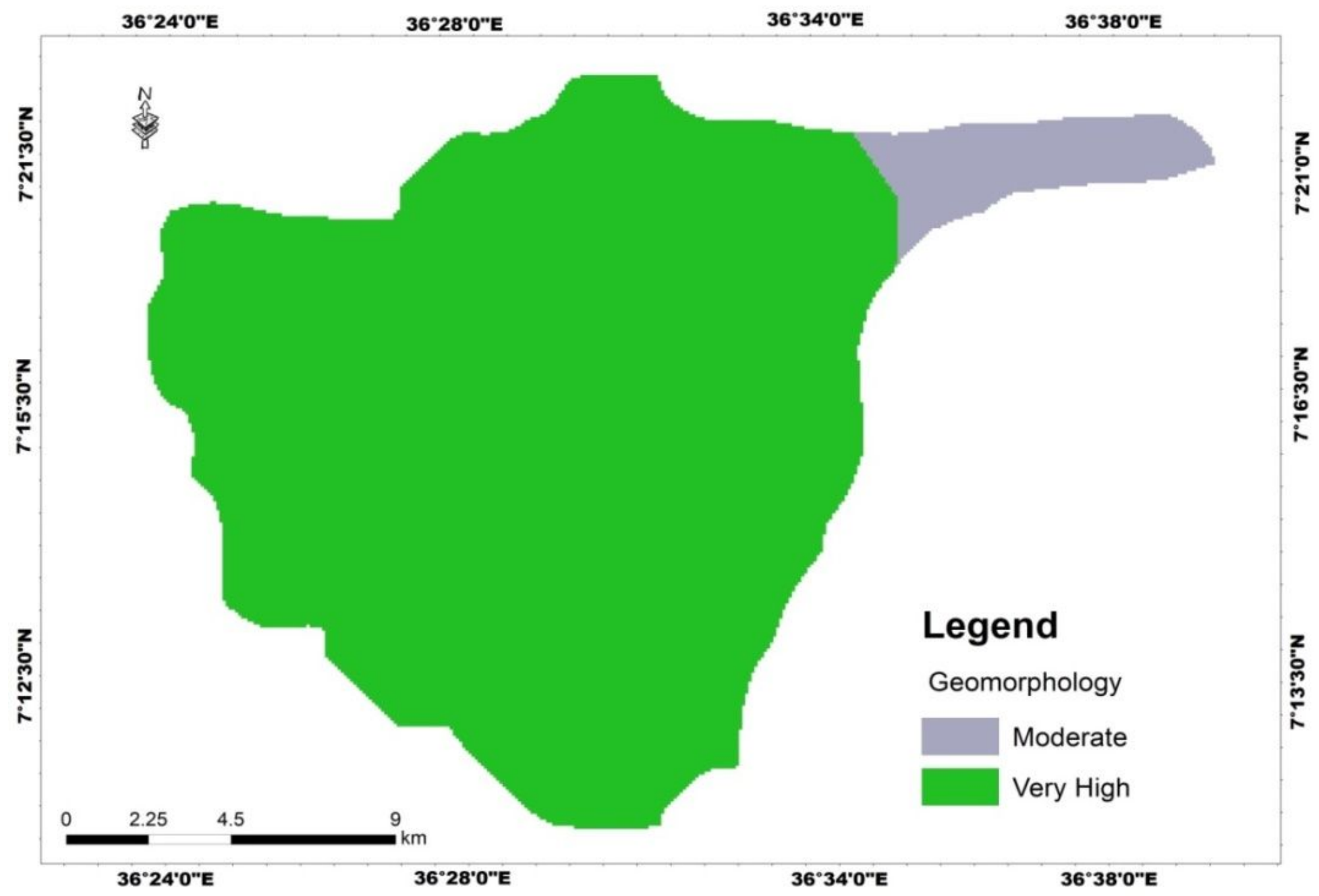

Figure 10

Reclassified Geomorphology map. Note: The designations employed and the presentation of the material on this map do not imply the expression of any opinion whatsoever on the part of Research Square concerning the legal status of any country, territory, city or area or of its authorities, or concerning the delimitation of its frontiers or boundaries. This map has been provided by the authors. 


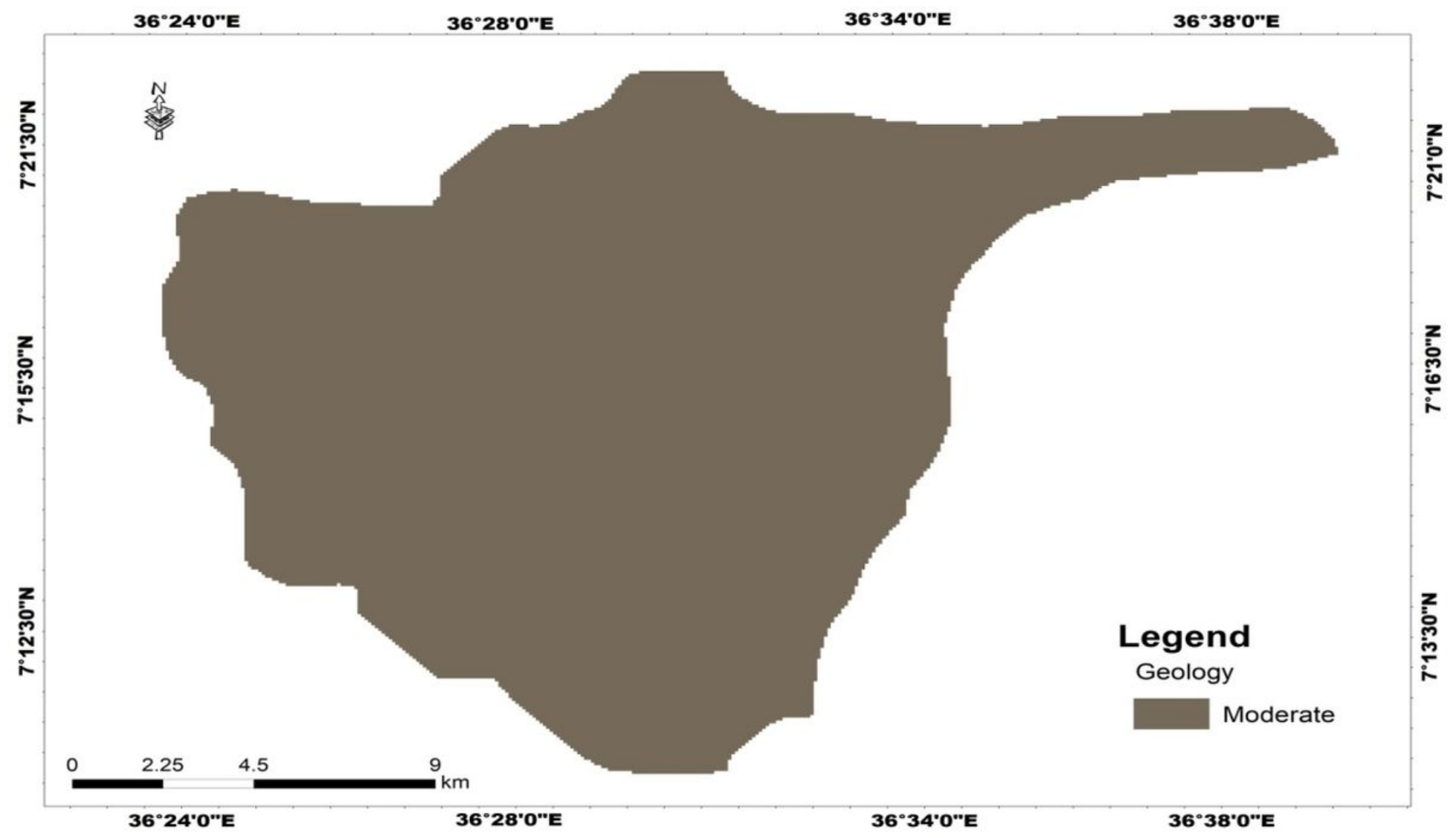

\section{Figure 11}

Reclassified Geology map. Note: The designations employed and the presentation of the material on this map do not imply the expression of any opinion whatsoever on the part of Research Square concerning the legal status of any country, territory, city or area or of its authorities, or concerning the delimitation of its frontiers or boundaries. This map has been provided by the authors. 


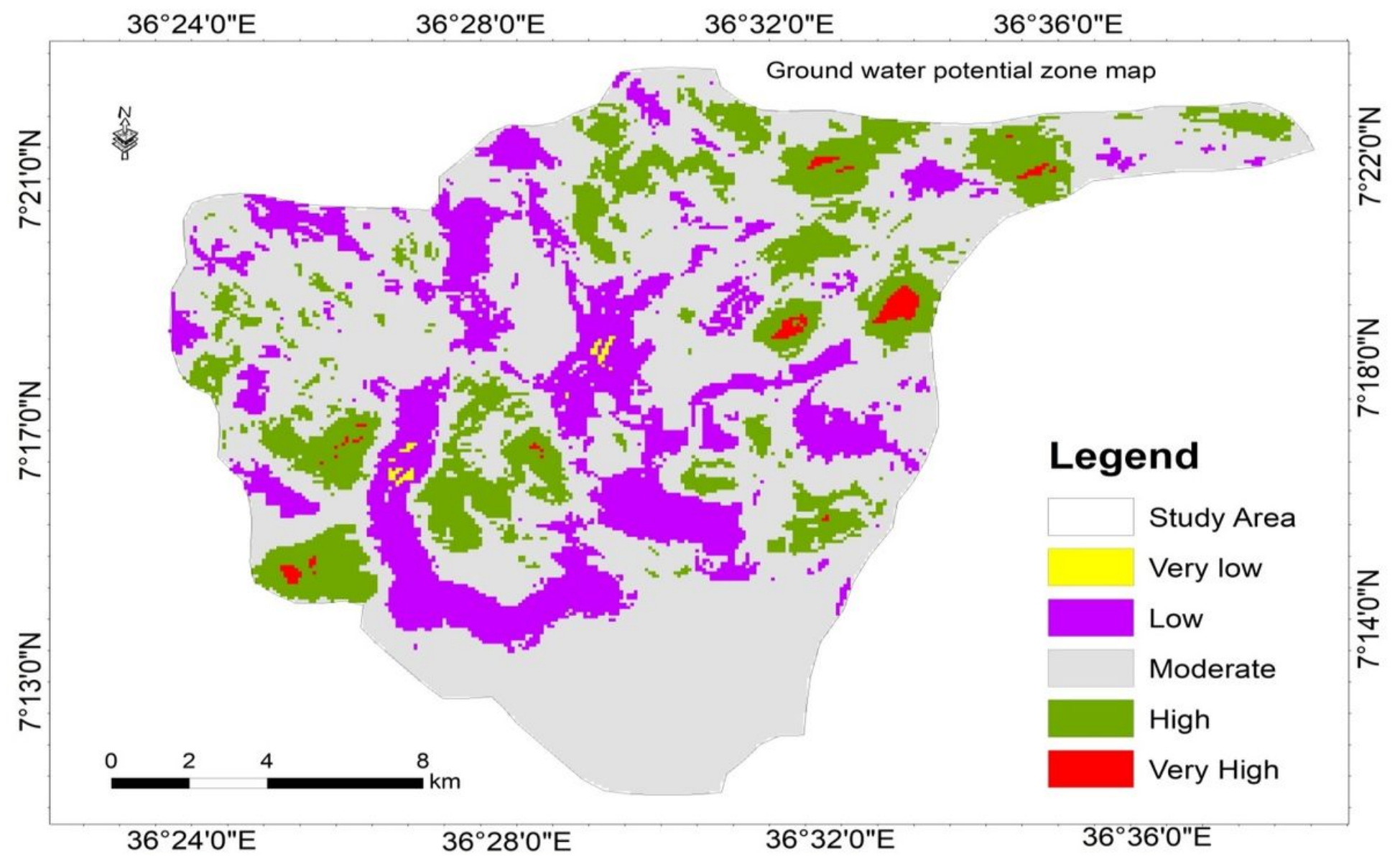

Figure 12

Groundwater Potential zones of map of odiyo watershed Note: The designations employed and the presentation of the material on this map do not imply the expression of any opinion whatsoever on the part of Research Square concerning the legal status of any country, territory, city or area or of its authorities, or concerning the delimitation of its frontiers or boundaries. This map has been provided by the authors. 